\title{
Financial performance of microfinance institutions in Kosovo
}

\author{
Jehona Shkodra \\ Department of Agro-economy, \\ Faculty of Agriculture and Veterinary University of Pristina, \\ Kosovo \\ jehona.shkodra@uni-pr.edu
}

Abstract. This article seeks to investigate the determinants of financial performance of microfinance institutions in Kosovo over the period of 2007-2016. The data has been taken from twelve microfinance institutions in Kosovo. The dependent variables used as proxies for microfinance institutions' (MFI) performance are Operational self-sufficiency (OSS), Return on Assets (ROA) and Profit Margin (PM). ROA and PM are widely used indicators to analyse financial performance or profitability of MFI. The findings of this study show that the most important factor which has strong impact on financial performance of MFIs in Kosovo is high interest rate on loans. Our results show that the age of MFI is the determinant that influences its financial performance. It can also be noted that MFI with better governance are those that are members of financial associations.

Keywords: microfinance institutions, financial performance, Kosovo, profit margin, return on assets and self-sufficiency.

JEL Classification: E4, E51, F65, G21

\section{INTRODUCTION}

The importance of MFIs for enhancing the welfare of poor people is well documented in literature and scientific research. MFIs have so far been quite successful in reducing poverty and promoting economic development, especially in rural areas, despite the fact that their offers are far more expensive than those of other financial institutions. Kosovo's financial industry, as in many countries in the region, has undergone major structural and innovative changes. The entry of foreign institutions into Kosovo financial market in the post-war period (1999) brought about development and restructuring of the financial market by applying international practices in the provision of services and variety of products within the financial industry. The increase in the number of financial institutions from year to year has led to an increase in the amount of funding by 40.5 percent and the reduction of interest rates by 63.8 percent from 2007 to 2016. This has also affected the improvement of competitive environment and improvement of the financial products' bids. 
Good functioning of the financial system is an important factor for channelling funds into the economy efficiently as a guarantee of economic development. Encouraging competition in the financial system is another factor that contributes to providing the best services to customers which includes sufficient funding, quality services and lower funding costs.

It has been noted that there are differences in the offers of financial institutions at our market, though not always in interest rates but in other supply points which are also very important such as the way of providing financial services, the speed of service delivery, the organization of service delivery etc.

The outbreak of war in 1999 and the lack of money in circulation have affected banks as a group of financial institutions to develop more and become leaders of the financial industry, thus directly influencing the development of other financial institutions, mostly MFIs, affecting their pricing and lender offering. The impact of banks on MFIs in Kosovo is twofold. First, they are the sources of financing for microfinance institutions; but secondly, they are also competing with MFIs in terms of loan offer. This has caused a disadvantage for microfinance in its development by pushing MFIsto be profiled in deficit areas in the lending bid due to the inability to compete with banks in the major part of lending offers. However, MFIs remain to be very important participants at the local financial market and they are more than necessary for the economic development of Kosovo overall.

Many researches have shown that microcredits' beneficiaries have not only managed to increase their incomes, but have also improved their business management level, thus improving healthcare and education services. Consequently, MFIs have had impact through making microcredit clients more confident in themselves in terms of their entrepreneurial activities. With this we can say that microfinance institutions focus on developing revenue-generating activities and reducing risks and uncertainties faced by businesses.

\section{LITERATURE REVIEW}

Microfinance deals with small financial services mainly in the form of loans to farmers and owners of small businesses. The term microfinance makes sense to provide financial services to low-income clients, including self-employed.

MFIs can provide farmers in-depth rural areas where the most of poor population lives. This process of alignment of financial institutions is present in Kosovo. Even though MFIs are present in Kosovo since 1999 no research has been done about MFIs' financial performance. In other countries we can find more research regarding MFIs' financial performance.

Among a few studies that examine the determinants of MFIs' financial performance are Nasrin et al. (2017) and Wijesiri et al. (2017), Daher and Le Saout (2015), Kharti (2014), Janda and Turbat (2013). Apart from that, several studies suggested that the MFIs' financial performance are determined by interest rate charged (Kar \& Swain, 2014; Roberts, 2013), size of the MFI (Cull et al., 2007), maturity of the MFI (Kar, 2011), and legal status of the MFI (Meyer, 2015; Tchakoute-Tchuigoua, 2010). The country context variables, such as inflation rate and GDP growth rate are also important in the financial performance analysis of MFIs (Nurmakhanova et al., 2015, Ahlin et al., 2011). Also Daher and Le Saout (2015) analyzed a global dataset from 2005 to 2011 and identified those MFIs that have high credit portfolio quality, large assets, high capital to assets ratio, low cost inefficiencies, large loans and high share of microcredit portfolios are financially outperformed.

Nasrin et al. (2017) focused on MFIs in Bangladesh over the period 2007-2013 as the financial performance indicators using portfolio yield and profit margin, but excluded other key financial performance indicators, such as, financial self-sufficiency (FSS), operational self-sufficiency (OSS) and return on assets (ROA) that may keep the findings ambiguous. Financial performance in financial 
institutions according to Stoner (2003) refers to profitability, operate efficiently, survive grow and react to the environmental opportunities and threats.

\section{METHODOLOGY}

This study is focused on Kosovo MFIs' financial performance, followed by the quantitative research approach. Thus, the article used data from twelve microfinance institutions in Kosovo for 10 years; from 2007-2016. Data for each MFI are collected from financial reports published by the Microfinance Institution or the Central Bank of Kosovo (CBK). According to the microfinance literature (Kumar Kar, A, 2011; Chan, S. H., \& Lin, J. J, 2015), the return on assets, the operational self-sufficiency, and the financial self-sufficiency are the main indicators that attempt to capture the complexity of financial performance.

In this study the dependent variables for MFI performance we used Operational self-sufficiency (OSS), Return on Assets (ROA) and Profit Margin (PM).

ROA and PM are widely used indicators to analyse financial performance or profitability of financial institutions, while OSS has been widely used in microfinance research. OSS is derived after dividing the operating income by the total of financial expense, operating expense and loan-loss expense.

Thus, in the event where the value of OSS of MFIs is equal to or greater than one, it is implied that the institutions are able to cover all its administrative expenses and loan losses from its operating income.

Table 1

Performance of MFI in Kosovo - Variables descriptions

\begin{tabular}{|c|c|}
\hline Variables & Definitions \\
\hline OSS: Operational self-sufficiency & $\begin{array}{l}\text { Financial Revenue / (Financial Expense + Impairment Losses } \\
\text { on Loans + Operating Expense) }\end{array}$ \\
\hline ROA: Return on Assets & $\begin{array}{l}\text { (Adjusted Net Operating Income - Taxes) / Adjusted Average } \\
\text { Total Assets }\end{array}$ \\
\hline PM: Profit Margin & Adjusted New Operating Income / Adjusted Financial Revenue \\
\hline Size & The natural logarithm of total assets in $€$ \\
\hline Age & $\begin{array}{l}\text { Number of years of experience as a microfinance } \\
\text { institution }\end{array}$ \\
\hline Network & $\begin{array}{l}\text { A dummy that equals } 1 \text { if the MFI is the member of national or } \\
\text { international network, } 0 \text { otherwise }\end{array}$ \\
\hline Inflation rate & Annual change in average consumer prices \\
\hline GDP growth rate & $\begin{array}{l}\text { Annual growth in the total output of goods and services } \\
\text { occurring within the territory of a given country }\end{array}$ \\
\hline Yield (nominal) & $\begin{array}{l}\text { Adjusted Financial Revenue from Loan Portfolio / Adjusted } \\
\text { Average Gross Loan Portfolio }\end{array}$ \\
\hline
\end{tabular}

Source: Prepared by the authors.

\section{Model specification}

Financial performance in MFI is the objective in this study. The OSS, ROA and PM are a general indicator that measures the profitability of financial institution. We include six independent variables (Yield, Size, Age, Network, Inflation, and GDP) which are commonly used in recent microfinance financial performance research (Table 1 shows descriptions of each variable). 
Based on the above discussion, a model of MFI financial performance can be estimated following the three specifications (1,2 and 3):

OSSit $=\alpha+\beta_{1}$ Yieldit $+\beta_{2}$ Sizeit $+\beta 3$ Ageit $+\beta 4$ Networkit $+\beta 5$ Inflationit $+\beta 6$ GDPit + uit.

ROAit $=\alpha+\beta_{1}$ Yieldit $+\beta_{2}$ Sizeit $+\beta 3$ Ageit $+\beta 4$ Networkit $+\beta 5$ Inflationit $+\beta 6$ GDPit + uit.

PMit $=\alpha+\beta_{1}$ Yieldit $+\beta_{2}$ Sizeit $+\beta 3$ Ageit $+\beta 4$ Networkit $+\beta 5$ Inflationit $+\beta 6$ GDPit + uit.

The $\mathrm{i}=1 \ldots ; \mathrm{N}$ for each MFI included in the study and $\mathrm{t}=1 \ldots ; \mathrm{T}$ refers to the time period.

Where:

- OSS is the operational self-sufficiency ratio of $\mathrm{i}$-th MFI. OSS measures how well an MFI is capable to cover its expenses from operating income it generates.

- $\quad$ ROA is the return on assets ratio of i-th MFI. The widely used profitability proxy ROA represents how well an MFI utilizes its total assets and operational revenues to bear costs or generate income.

- PM is the profit margin ratio of i-th MFI. PM portrays the percentage of operating revenue remains after all financial, loan-losses provision, and operating expenses are paid.

The Yield is the nominal gross portfolio yield, a proxy measure of interest rate charged by the MFIs on its clients.

The matrix Yield employed in the model summarizes its effect on the OSS, ROA and PM respectively.

The coefficient matrix $\beta_{2}$ includes size (natural logarithm of total assets) to explain its impact on the financial attainment.

The coefficient matrix $\beta 3$ involves the Age (natural logarithm of operating years) of MFIs to identify its influence on the financial progress.

The coefficient matrix $\beta 4$ shows network membership. MFIs that maintain the membership within national or international association have been categorized in this matrix as dummy variables.

The coefficient matrix $\beta 5$ shows inflation, and coefficient matrix $\beta 6$ show GDP which is included to control for the effect of financial viability, since the economic condition and the environment vary from country to country.

\section{EMPIRICAL RESULTS AND DISCUSSION}

Table 2 summarizes the regression results for all selected MFIs for the period 2007-2016. The results of the Hausman test (Prob> chi2> 10\%) show that the random effects model should be chosen on the model of fixed effects.

Table 2

Summary descriptive statistics

\begin{tabular}{|l|c|c|c|c|c|}
\hline \multicolumn{1}{|c|}{ Variables } & Number of MFI & Mean & Standard Deviation & Min & Max \\
\hline OSS & 12 & 1.09 & 0.18 & 0.58 & 2.31 \\
\hline ROA & 12 & 6.9 & 0.05 & 0.41 & 8.18 \\
\hline PM & 12 & 0.24 & 0.28 & 0.17 & 0.61 \\
\hline Size & 12 & 21.11 & 1.40 & 24.23 & 39.13 \\
\hline Age & 12 & 15.49 & 7.75 & 8 & 18 \\
\hline Yield & 12 & 0.37 & 0.13 & -0.17 & 0.69 \\
\hline GDP & 12 & 5.10 & 2.57 & -4.40 & 7.39 \\
\hline Inflation & 12 & 2.03 & 1.63 & 0 & 14.20 \\
\hline Network & 12 & 0.21 & 0.15 & & 1 \\
\hline
\end{tabular}

Source: Authors' calculations, based on data from the Central Bank of Kosovo and MFI 
The results from Table 2 show the value above 1 for mean value of OSS, suggesting that the MFI in Kosovo are in a good way in terms of earning expenses-covering revenue.

The summarized values taken for ROA, where the mean value is 6.9 percent indicates that the return on assets of MFIs in Kosovo is low.

The summarized values of $\mathbf{P M}$ vary from 0.17 to 0.61 and the mean value of 24 percent, simply shows that average of the selected MFIs are attaining lower profit margins.

The mean value of 21 percent for Size indicates that only 21 percent of all MFI in Kosovo owns fixed assets. At the Age we find the average functioning years as MFI in general are little over 15.5 years, but if we compare it with the age of Kosovo as state then we can say that the majority of sampled MFIs are matured.

The Yield rate is between -17 percent to 70 percent that simply referring sampled MFIs is quite disproportionately distributed. The average 37 percent nominal yield is low.

The GDP rate is between 1.85 percent to 7.39 percent, and with an average of 5 percent GDP growth rate, which reflected economic normality.

The mean value of Inflation rate is only 2 percent which reflected stability economic on the place. Based on the fact that the MFIs have only one association in which they can join, for that the membership is limited.

The correlations in table 3 show a positive correlative, where many correlations are significant, but all are less than 0.9. Based on Kennedy (2008) there is no indication of multicollinearity issues here. Unlike from that we didn't find significant correlation network.

Table 3

Correlation between independent variables

\begin{tabular}{|l|c|c|c|c|c|c|}
\hline & Yield & Size & Maturity & Network & Inflation & GDP \\
\hline Yield & 1 & & & & & \\
\hline Size & $0.2848^{*}$ & 1 & & & & \\
\hline Age & $-0.3834^{*}$ & $0.1408^{*}$ & 1 & & & \\
\hline Network & $0.1439^{*}$ & $0.1439^{*}$ & $0.1439^{*}$ & 1 & & \\
\hline Inflation & $0.2788^{*}$ & $0.2788^{*}$ & $0.2788^{*}$ & $0.2788^{*}$ & 1 & \\
\hline GDP & 0.1146 & 0.0487 & $0.1532^{*}$ & 0.0034 & 0.1146 & 1 \\
\hline
\end{tabular}

Note: correlation is significant at the $5 \%$ level.

Table 4 shows the variation inflation factor (VIF) which detects multicollinearity in regression analysis, when at our case the data which we find are up 1 and less 5 and based on rule $1<$ VIF $<5$ they are moderately correlated. In regression models for all the independent variables is not greater than 10 which rules out any problem of multicollinearity (Hair et al., 2010; Ibrahim, at al., 2018).

Table 4

Variance inflation factor (VIF)

\begin{tabular}{|l|c|c|c|c|c|c|}
\hline \multirow{2}{*}{ Variables } & \multicolumn{2}{|c|}{ OSS } & \multicolumn{2}{c|}{ ROA } & \multicolumn{2}{c|}{ PM } \\
\cline { 2 - 7 } & VIF & 1/VIF & VIF & 1/VIF & VIF & $1 /$ VIF \\
\hline Size & 1.85 & 0.540540541 & 1.85 & 0.540540541 & 1.85 & 0.540540541 \\
\hline Age & 3.58 & 0.279329609 & 3.58 & 0.279329609 & 3.58 & 0.279329609 \\
\hline Inflation & 1.08 & 0.925925926 & 1.08 & 0.925925926 & 1.08 & 0.925925926 \\
\hline GDP & 2.28 & 0.438596491 & 2.28 & 0.438596491 & 2.28 & 0.438596491 \\
\hline Yield & 4.11 & 0.243309002 & 4.11 & 0.243309002 & 4.11 & 0.243309002 \\
\hline Network & 1.43 & 0.699300699 & 1.43 & 0.699300699 & 1.43 & 0.699300699 \\
\hline Mean VIF & 2.40 & & 2.40 & & 2.40 & \\
\hline
\end{tabular}

Source: Prepared by the authors. 
Table 5 summaries the results of the analyses, it's shows the performance of MFIs in Kosovo across three financial performance indicators (OSS, ROA and PM).

The Size of MFI in Kosovo is found to have a positive significant association across all three financial performance indicators. We find positive significant at Age, and from the results we can conclude that those MFIs who function for a longer period in the market have more experience and likelihood of obtaining better operational self-sufficiency and return on assets than MFIs that are newly established.

The inflation variables present statistically significant results, especially with OSS and ROA.

The GDP rate is highly significant but at report with financial performance is negative, which show inverse relation with all three financial performance indicators.

One of most important coefficient to reflect financial performance indicates is gross portfolio yield which give us positive significantly across three financial performance indicators. From the result we can conclude that the MFI which charges high-interest rate will be able to be more profitable compared to those MFI which charges lower interest rate. The results of the analyses loans to clients from the measure of nominal interest rates is significantly positive in OSS, ROA and PM (financial performance indicators).

The network presents not statistically significant results across all the financial performance indicators.

Table 5

The financial performance of MFIs in Kosovo

\begin{tabular}{|l|c|c|c|}
\hline \multicolumn{1}{|c|}{ Variables } & OSS & ROA & PM \\
\hline Size & $0.159^{* * *}$ & $0.00121^{* * *}$ & $0.0456^{* * *}$ \\
\hline Age & $(0.0428)$ & $(0.00364)$ & $0.00237)$ \\
\hline & $0.235^{* * *}$ & $0.0271^{* * *}$ & $(0.0574)$ \\
\hline Inflation & $(0.0389)$ & $(0.0478)$ & 0.00283 \\
\hline & $0.00101^{* * *}$ & $0.00208^{* * *}$ & $(0.00111)$ \\
\hline GDP & $(0.00124)$ & $(0.000241)$ & $-0.00132^{* *}$ \\
\hline & $-0.00484^{* *}$ & $-0.00356^{* *}$ & $(0.00118)$ \\
\hline Yield & $(0.00141)$ & $(0.000172)$ & $0.230^{* * *}$ \\
\hline & $0.373^{* * *}$ & $0.142^{* * *}$ & $(0.0356)$ \\
\hline Network & $(0.124)$ & $(0.00519)$ & 0.142 \\
\hline & 0.311 & 0.728 & $(0.0253)$ \\
\hline Constant & $(0.0333)$ & $(0.0799)$ & $0.245^{* * *}$ \\
\hline & $0.456^{* *}$ & $0.153^{* * *}$ & $(0.123)$ \\
\hline R-squared & $(0.147)$ & $(0.169)$ & 0.316 \\
\hline Observations & 0.312 & 0.341 & 10 \\
\hline
\end{tabular}

Note: Significant at the level where ${ }^{*} p<0.10 ;{ }^{* *} p<0.05$ and ${ }^{* * *} p<0.01$.

\section{CONCLUSION}

The findings of this study show that the main conclusion is that MFIs with higher interest rates are more profitable. From the results we have noted that there is an important relationship between MFI financial performance and size, year, inflation and GDP and there are no significant relationships from membership. The unrelated relationship of membership is considered to be based on the fact that MFIs in Kosovo do not exercise membership in associations and this is evidenced by the current situation where from 16 MFIs operating in Kosovo, only eight of them are members of the Association of microfinance institution in Kosovo (AMIK). 
Researchers and studies suggest that maintaining membership on the national or international network helps to increase the institution's operations and generate better benefits.

Despite the fact that high interest rates create high profit for MFIs, I suggest that the IMF should lower interest rates and as a source of maximizing their profits they should use spending cuts. MFIs should also keep membership in financial associations because in research conducted in European countries where MFIs are members of any association, they have generated good benefits. As there is a small number of MFIs involved in research, despite the good performance of MFIs which are members of the Association of Microfinance Institutions, this in generally is not identified as an influencing factor.

\section{REFERENCES}

Ahlin, C., Lin, J., \& Maio, M. (2011). Where does microfinance flourish? Microfinance institution performance in macroeconomic context. Journal of Development economics, 95(2), 105-120.

Butcher, W., \& Galbraith, J. (2019, January). Microfinance control fraud in Latin America. In Forum for Social Economics (Vol. 48, No. 1, pp. 98-120). Routledge.

Chan, S. H., \& Lin, J. J. (2015). Microfinance Products and Service Quality in Financial and Quasi-Financial Institutions in China. Strategic Change, 24(3), 267-284.

Cull, R., Demirgu“" ç-Kunt, A., \& Morduch, J. (2007). Financial performance and outreach: A global analysis of leading microbanks. The Economic Journal, 117(517), F107-F133.

Daher, L., \& Le Saout, E. (2015). The determinants of the financial performance of microfinance institutions: Impact of the global financial crisis. Strategic Change, 24(2), 131-148.

Dehem, T., \& Hudon, M. (2013). Microfinance from the clients' perspective: An empirical enquiry into transaction costs in urban and rural India. Oxford Development Studies, 41(sup1), S117-S132.

Katan, L., \& Espejo, J. M. R. (2018). Structural modeling of the financial support for the Ukrainian agrarian sector. Investment Management \& Financial Innovations, 15(3), 199.

Janda, K., \& Turbat, B. (2013). Determinants of the financial performance of microfinance institutions in Central Asia. Post-Communist Economies, 25(4), 557-568.

Kumar Kar, A. (2011). Microfinance institutions: A cross-country empirical investigation of outreach and sustainability. Journal of Small Business \& Entrepreneurship, 24(3), 427-446.

Kar, A. K., \& Swain, R. B. (2014). Interest rates and financial performance of microfinance institutions: Recent global evidence. The European Journal of Development Research, 26(1), 87-106.

El Kharti, L. (2014). The determinants of financial performance of microfinance institutions in Morocco: A panel data analysis.

Meyer, J. (2015). Social versus financial return in microfinance. Available at SSRN 2580343.

Nasrin, S., Rasiah, R., Baskaran, A., \& Masud, M. M. (2018). What determines the financial performance of microfinance institutions in Bangladesh? a panel data analysis. Quality \& Quantity, 52(3), 1409-1422.

Nurmakhanova, M., Kretzschmar, G., \& Fedhila, H. (2015). Trade-off between financial sustainability and outreach of microfinance institutions. Eurasian Economic Review, 5(2), 231-250.

Roberts, P. W. (2013). The profit orientation of microfinance institutions and effective interest rates. World Development, 41, 120-131

Tchakoute-Tchuigoua, H. (2010). Is there a difference in performance by the legal status of microfinance institutions?. The Quarterly Review of Economics and Finance, 50(4), 436-442.

Wijesiri, M., Yaron, J., \& Meoli, M. (2017). Assessing the financial and outreach efficiency of microfinance institutions: Do age and size matter?. Journal of Multinational Financial Management, 40, 63-76. 